\title{
Improving the estimation of deep-sea megabenthos biomass: dimension to wet weight conversions for abyssal invertebrates
}

\author{
Jennifer M. Durden ${ }^{1,2, *}$, Brian J. Bett ${ }^{1}$, Tammy Horton ${ }^{1}$, Amanda Serpell-Stevens ${ }^{1}$, \\ Kirsty J. Morris ${ }^{1}$, David S. M. Billett ${ }^{1}{ }$ Henry A. Ruhl ${ }^{1}$ \\ ${ }^{1}$ National Oceanography Centre, European Way, Southampton SO14 3ZH, UK \\ ${ }^{2}$ Ocean and Earth Science, University of Southampton, National Oceanography Centre Southampton, European Way, \\ Southampton SO14 3ZH, UK
}

\begin{abstract}
Deep-sea megafaunal biomass has typically been assessed by sampling with benthic sledges and trawls, but non-destructive methods, particularly photography, are becoming increasingly common. Estimation of individual wet weight in seabed photographs has been achieved using equations obtained from measured trawl-caught specimens for a limited number of taxa. However, a lack of appropriate conversion factors has limited estimation across taxa encompassing whole communities. Here we compile relationships between measured body dimensions and preserved wet weights for a comprehensive catalogue of abyssal epibenthic megafauna, using 47 000 specimens from the Porcupine Abyssal Plain (NE Atlantic) housed in the Discovery Collections (National Oceanography Centre, Southampton, UK). The practical application of the method is demonstrated using an extremely large dataset of specimen measurements from seabed photographs taken in the same location. We also collate corresponding field data on fresh wet weight, to estimate the impact of fixation in formalin and preservation in industrial denatured alcohol on the apparent biomass. Taxa with substantial proportions of soft tissues lose 35 to $60 \%$ of their wet weight during preservation, while those with greater proportions of hard tissues lose 10 to $20 \%$. Our total estimated fresh wet weight biomass of holothurians and cnidarians in the photographic survey was $\sim 20$ times the previous estimates of total invertebrate biomass based on trawl catches. This dramatic uplift in megabenthic biomass has significant implications for studies of standing stocks, community metabolism, and numerical modelling of benthic carbon flows.
\end{abstract}

KEY WORDS: Biomass · Invertebrate - Preservation · Wet weight · Photograph · Deep sea · Porcupine Abyssal Plain

\section{INTRODUCTION}

Deep-sea epibenthic invertebrate megafaunal biomass has typically been assessed by sampling with sledges and trawl nets (Gage \& Bett 2005). Our current understanding of the ecology of these assemblages is based on these techniques, including studies of community dynamics over time (Billett et al.

${ }^{*}$ Corresponding author: jennifer.durden@noc.soton.ac.uk
2001) and space (Alt et al. 2013), food web interactions (van Oevelen et al. 2012), the potential links between resource availability and community dynamics (Ruhl et al. 2014), and their contributions to large-scale and global assessments of standing stocks (Rex et al. 2006, Wei et al. 2010). Although trawling and similar approaches are necessary to obtain specimens for taxonomy, histology, and genet-

(C) The authors 2016. Open Access under Creative Commons by Attribution Licence. Use, distribution and reproduction are unrestricted. Authors and original publication must be credited. 
ics, such samples have major quantitative uncertainty in terms of the seabed area sampled, and likely do not accurately represent the megabenthic community present (Rice et al. 1979, Bett et al. 2001).

The investigation of deep-sea communities has increasingly favoured non-destructive methods, primarily photography (Jamieson et al. 2013), which can produce quantitative data on the megabenthos (Jones et al. 2009, Smith \& Rumohr 2013). Trawling has long been known to provide semi-quantitative sampling of megabenthic biomass, as a result of variable coverage and poor quantification of the seabed area sampled by trawls (Gage \& Tyler 1991), lower catching efficiency of trawls, and body-size- and tissue-typebased variation in trawl efficiency (Owen et al. 1967, Rice et al. 1979, Smith \& Hamilton 1983, Bett et al. 2001, Durden et al. 2015b). Large photographic surveys of the seabed have revealed substantially higher standing stocks of deep-sea megabenthos than corresponding trawl catch data (Morris et al. 2014, Durden et al. 2015a), thus the use of seabed photography to improve quantification of biomass is logical and of potentially substantial significance to our understanding of deep-sea ecology in general, and carbon budgets in particular. For example, consider the expectation that the distribution of biomass in marine communities may be constant across logarithmic size classes (Sheldon et al. 1972), or increase continuously in logarithmic classes among the benthos (Bett 2013, Kelly-Gerreyn et al. 2014). Consequently, a substantial fraction of standing stock carbon may be represented by the megabenthos that are currently grossly underestimated from trawl catch data.

Some previous photographic studies have estimated megafaunal biomass using abundances estimated from photographs in combination with mean wet weights of trawled specimens, largely in highlevel taxonomic groupings for key faunal groups (e.g. Smith \& Hamilton 1983, Thresher et al. 2011). Detailed estimation of abyssal invertebrate wet weights from dimensions measured in seabed photographs has been achieved for echinoderms (Ruhl et al. 2014), and for high-level taxonomic groupings at the MidAtlantic Ridge (Alt et al. 2013) and the northeast Atlantic (Christiansen \& Thiel 1992). Further conversions between body length wet weight from trawlcaught specimens have been published for individual species (e.g. Enypniastes eximia; Bailey et al. 1994). However, a lack of appropriate conversion factors for many taxa has limited estimation across complete megafaunal communities.

Here we establish a comprehensive compilation of relationships between measured body dimensions and preserved wet weights for abyssal epibenthic megafauna from the Porcupine Abyssal Plain (PAP; NE Atlantic). We accessed specimens from the exceptional archive of trawl-caught megabenthos housed in the Discovery Collections at the National Oceanography Centre, Southampton, UK. We develop links between those data and an extremely large dataset of specimens measured from seabed photographs taken in the same location, to test the practical application of the method. We collate corresponding field data on fresh wet weight, to estimate the impact of preservation on the apparent biomass of the megabenthos assemblage. Finally, we illustrate the significance of our approach by comparison with previously published estimates of PAP megafaunal biomass.

\section{MATERIALS AND METHODS}

\section{Dimension to wet weight conversions from trawled specimens}

Conversions were created using $\sim 4000$ specimens collected in the vicinity of the Porcupine Abyssal Plain Sustained Observatory Site (PAP; $48^{\circ} 50^{\prime} \mathrm{N}$, $16^{\circ} 30^{\prime} \mathrm{W}, 4850 \mathrm{~m}$ water depth; Hartman et al. 2012) using a semi-balloon otter trawl (Billett et al. 2001) on a number of research cruises between August 1996 and October 2002: RRS 'Discovery' 222 (Rice 1996), 226 (Rice 1997), 229 (Bett 1998), 231 (Rice 1998), 237 (Sibuet 1999), and 266; and RRS 'Challenger' 135 (Billett 1998) and 142 (Billett 2000). Specimens were fixed in borax-buffered $10 \%$ formalin-seawater at sea, and subsequently transferred to $80 \%$ industrial denatured alcohol for long-term preservation once ashore (generally within 2 months of sample collection). For the analyses presented here, specimens were reduced to those considered to be complete and intact (e.g. including coelemic fluid in the case of holothurians). Damaged and/or partial specimens were excluded, except in the case of ophiuroids and brisingids, for which no complete, intact specimens were available. Recommendations for the processing of fluid-preserved specimens (Simmons 2014) were generally followed.

Physical dimensions and wet weights were recorded for each specimen. The dimension selected was generally the linear 'length' (Table 1). In asteroids, the radius from the centre of the disk to the end of an outstretched arm was measured. A similar measurement was made for ophiuroids, and the disk diameter was also measured. The column diameter 
Table 1. Dimension to preserved wet weight conversions created from specimens collected in trawls of the form: preserved wet weight $(\mathrm{g})=A \times$ dimension $(\mathrm{mm})^{B}$ (see Eq. 1), where $A$ and $B$ are coefficients fitted using linear regression of the logarithm of the formula. Measured dimensions, not including appendages (e.g. tentacles, papillae, antennae, etc.): $L=$ length, $D=$ diameter, $R=$ radius from centre of disk to end of arm

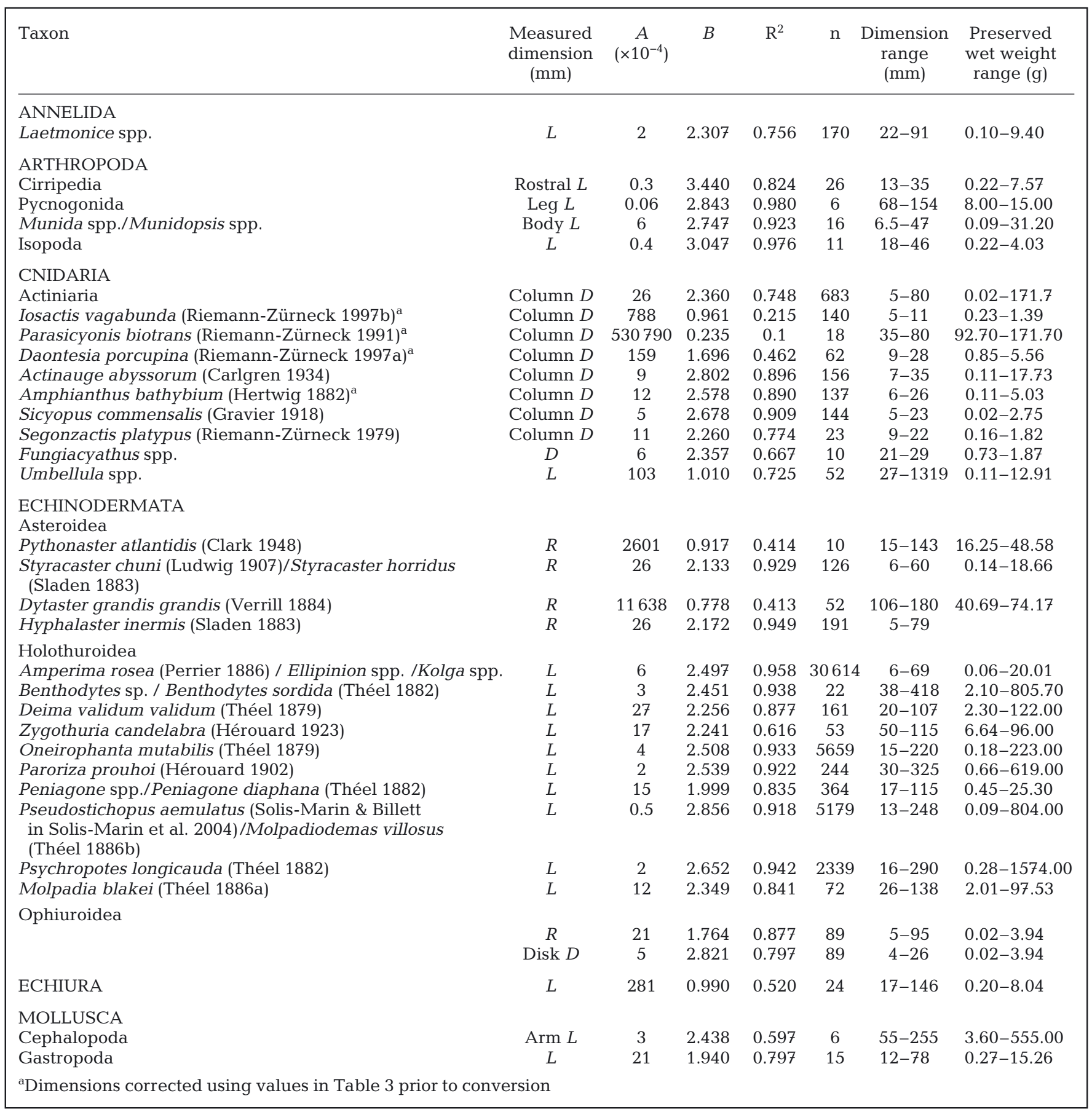

was measured in anemones. The length of the longest leg was measured in pycnogonids. Otherwise, appendages were excluded, particularly those that are flexible or retractable, such as the vellum and papillae in holothurians. Visible surface liquid was removed by blotting using absorbent towel prior to weighing. Wet weights of crustaceans, echinoderms, and molluscs included the shells. In taxa for which dimensions could not be reproducibly measured (Table 2), only wet weights were recorded. 
Power relationships were established between the measured dimension and the preserved wet weight of the specimen, with the form:

$$
P=A \times L^{B}
$$

where $P$ is the preserved wet weight $(g), L$ is the measured dimension (mm), and $A$ and $B$ are coefficients fitted using linear regression of the logarithm of the formula above. An $\mathrm{R}^{2}$ value was computed to evaluate the goodness of fit. Preliminary relationships were presented in Durden et al. (2015a).

\section{Application to seabed photographs}

These conversions were applied to individuals identified and measured in 28200 seabed photographs (representing some 3.6 ha of seabed) from the PAP site obtained with the Autosub6000 autonomous underwater vehicle from RRS 'Discovery' research cruise 377 (Ruhl 2013, Morris et al. 2014). Methods for image processing and annotation are detailed in Morris et al. (2014); in brief, distinctly identifiable megafauna were classified and measured in vertical seabed photographs, following processing of the images to correct for camera orientation. Image pixel dimensions were converted to physical units using the altitude and orientation of the camera (Jones et al. 2009, Morris et al. 2014).

Invertebrates were identified to the lowest practicable taxonomic levels, which was not always to the same detail for specimens in photographs as for those caught in trawls. Matching morphotypes identified in photographs to taxa identified in the trawl catches was not always straightforward. Some morphotypes differ in appearance as a result of trawl capture and subsequent fixation (e.g. retraction of tentacles and contraction of oral disk in anemones, retraction of papillae in holothurians). In cases where specimens from multiple species were grouped, this is indicated in Tables 1 \& 2 .

Some morphotypes presented difficulties in the selection of a measured dimension that was practical in the photographs, and matched the dimension measured of the preserved specimens. Fig. 1 shows examples of the measured dimensions in images that were also possible in preserved specimens. For certain anemones, a common measured dimension in both the photographs and preserved specimens was not practical, so a further conversion between the dimension measured in preserved specimens (column diameter) and the dimension measured in photographs (oral disk diameter) was applied (Fig. 1).
Table 2. Individual specimen preserved wet weight data for Porcupine Abyssal Plain taxa where reliable dimension measurement was not possible

\begin{tabular}{|llcc|}
\hline Taxon & $\begin{array}{c}\text { Range } \\
(\mathrm{g})\end{array}$ & $\begin{array}{c}\text { Median } \\
(\mathrm{g})\end{array}$ & $\mathrm{n}$ \\
\hline $\begin{array}{l}\text { TUNICATA } \\
\text { Culeolus spp. }\end{array}$ & $0.01-2.02$ & 0.34 & 1599 \\
CNIDARIA & & & \\
Zoantharia & $0.01-0.43$ & 0.10 & 538 \\
ECHINODERMATA & & & \\
$\begin{array}{l}\text { Freyastera spp./Freyella spp. } \\
\text { Pterasteridae }\end{array}$ & $0.07-17.67$ & 0.87 & 312 \\
Crinoidea & $0.33-8.67$ & 4.5 & 2 \\
PORIFERA & $0.05-1.59$ & 0.7 & 13 \\
\hline
\end{tabular}

These conversions were established by measuring both dimensions in a subset of images where both dimensions could be observed, and were applied to image measurements prior to wet weight conversion. Power relationships were established between the column diameter and the disk diameter (Table 3), with the form:

$$
C=G \times D^{H}
$$

where $C$ is the column diameter (pixels), $D$ is the oral disk diameter (pixels), and $G$ and $H$ are coefficients fitted using linear regression of the logarithm of the formula above. An $\mathrm{R}^{2}$ value was computed to evaluate the goodness of fit. The underestimation of the measured dimension is acknowledged in taxa where legs or arms may not be extended fully in photographs (e.g. pycnogonids, brisingids), but measurements of preserved specimens would be of extended appendages.

\section{Preserved to fresh wet weight conversions}

Conversions between fresh wet weights, measured at sea, and preserved wet weights following fixation in buffered formalin and preservation in industrial denatured alcohol were established using batch wet weights of trawl-caught specimens, aggregated by taxon, collected from RRS 'Discovery' 237 (Sibuet 1999), RRS 'Discovery' 229 (Bett 1998), and RRS 'Challenger' 142 (Billett 2000). Again, recommendations for the processing of fluid-preserved specimens (Simmons 2014) were generally followed. Note that these batch weights included all specimens (including both damaged and intact specimens) in the determinations of both preserved and fresh weights. Con- 

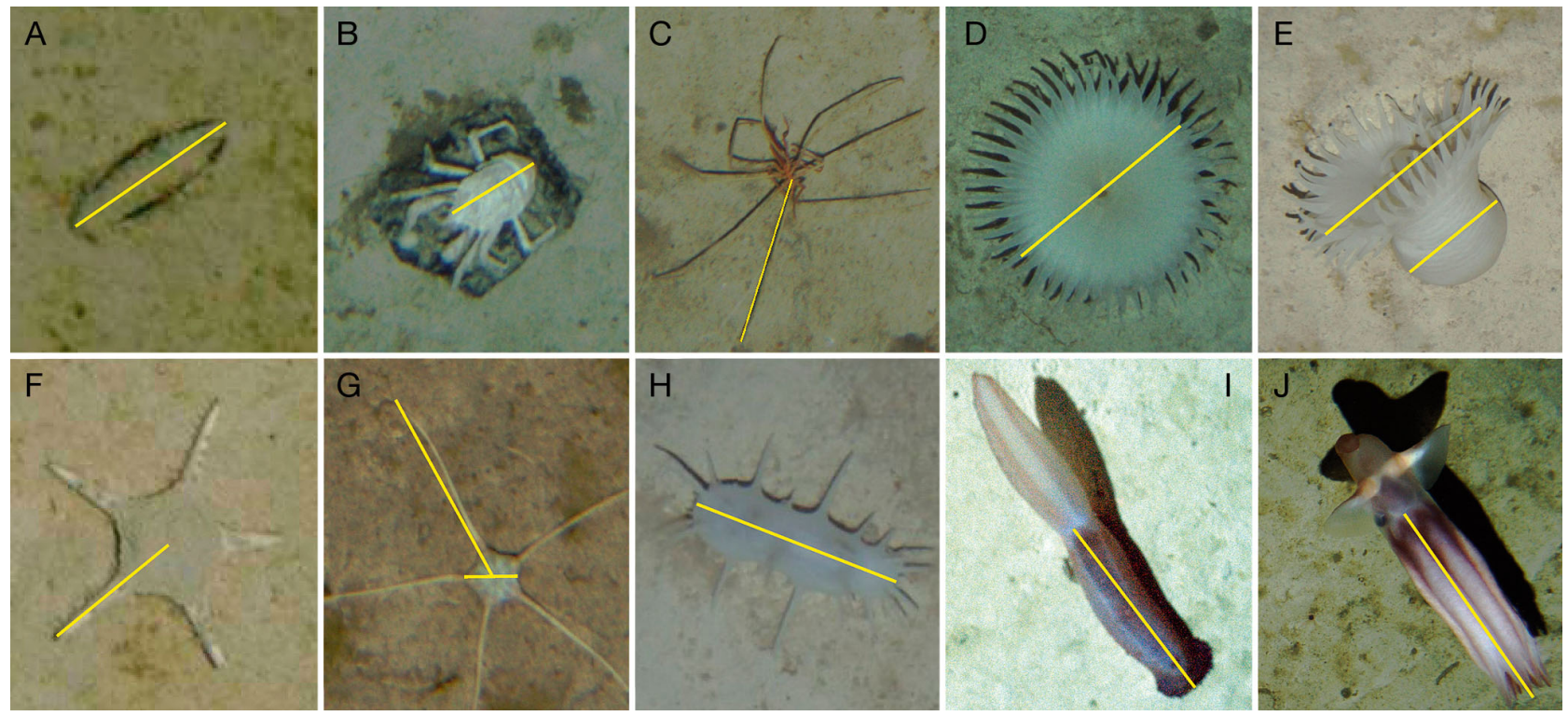

Fig. 1. Example measured dimensions (in yellow) of representative morphotypes: (A) body length of Annelida - Laetmonice spp.; (B) length of Arthropoda - Munidopsis spp.; (C) leg length of Pycnogonida; (D) oral disk diameter of Cnidaria - Parasicyonis sp., see also (E) the disk and column diameters as measured in trawl-caught specimens (see Table 2); (F) radius from body centre to end of arm of Echinodermata, Asteroidea - Styracaster spp.; (G) alternate measurements of disk diameter and radius from body centre to end of arm of Echinodermata - Ophiuroidea; $(\mathrm{H})$ body length of Echinodermata, Holothuroidea - Oneirophanta mutabilis, also note (I) body length excluding sail of Psychropotes longicauda; (J) arm length of Mollusca - Cephalopoda

Table 3. Conversion from photograph-measured dimension (oral disk diameter, $D$, pixels) to preserved specimen dimension (column diameter, $C$, pixels). Conversion is in the form: $C=G \times D^{H}$ (see Eq. 2), where $G$ and $H$ are factors in a relationship determined from $n$ individuals, with goodness of fit, $\mathrm{R}^{2}$

\begin{tabular}{|lcccc|}
\hline Morphotype & $G$ & $H$ & $\mathrm{R}^{2}$ & $\mathrm{n}$ \\
\hline Iosactis vagabunda & 0.414 & 1.075 & 0.81 & 45 \\
Parasicyonis biotrans & 0.015 & 1.614 & 0.86 & 5 \\
Daontesia porcupina & 2.527 & 0.599 & 0.71 & 5 \\
Amphianthus bathybium & 0.114 & 1.283 & 0.83 & 8 \\
\hline
\end{tabular}

sequently, apparent data outliers (e.g. samples for which fresh wet weights included attached clinker in anemones) were identified, evaluated using Q-Q plots and Cook's distance in R software (R Core Team 2015), and removed. Following this data editing, relationships were established of the form:

$$
P=J \times F
$$

where $P$ is the preserved wet weight $(\mathrm{g}), F$ is the fresh wet weight $(\mathrm{g})$ and $J$ is a coefficient determined by linear least-squares regression fitted in $\mathrm{R}$ ( $\mathrm{R}$ Core Team 2015) with zero intercept.

Total biomass ( $\mathrm{g}$ fresh wet weight $\mathrm{ha}^{-1}$ ) was calculated by converting the measured dimension for each specimen observed in the seabed photographs to fresh wet weight using the methods detailed above, and summing for each morphotype. For morphotypes for which no specific conversions were available, estimates were based on conversions for the nearest morphological analogue.

\section{RESULTS AND DISCUSSION}

Dimension to preserved wet weight conversions for 34 taxa are presented in Table 1, and preserved wet weights of a further 6 taxa for which dimensions could not be measured are given in Table 2. Published size and preserved wet weight data are scarce for many deep-sea taxa, so we have included values for as many groups as possible. The number of specimens available per taxon ranged from 6 to 44630 , with 24 of the conversions based on at least 50 specimens. The goodness of fit of the conversions derived from the trawl catch data $\left(\mathrm{R}^{2}\right)$ varied between taxa, with 24 conversions having values of at least 0.75 . Conversions computed from small numbers of specimens should of course be treated with caution.

For some taxa, the trawled specimens represented a wide range of dimensions and preserved wet weights (e.g. Fig. 2A,B), likely encompassing much of the sea- 

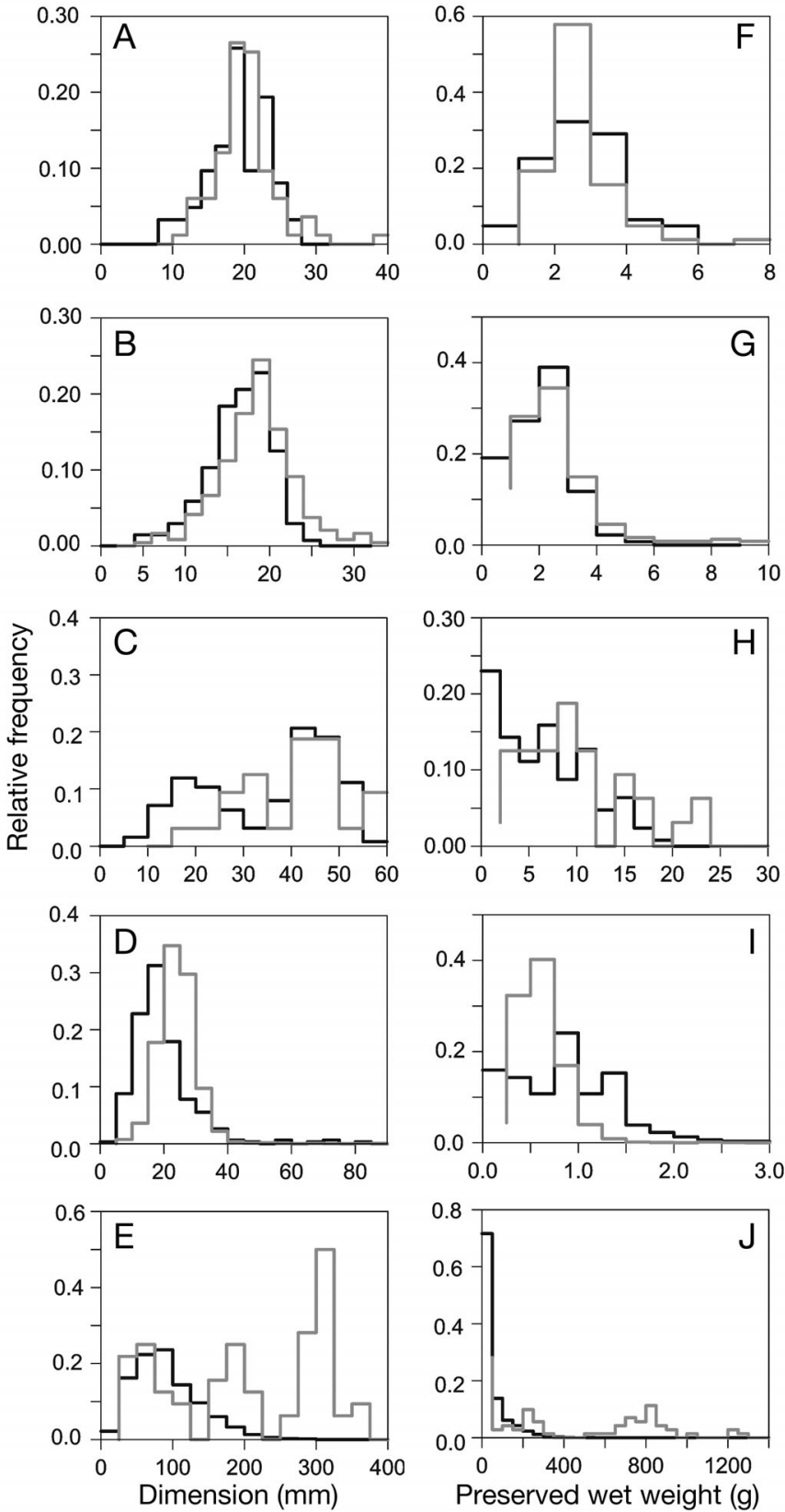

Fig. 2. Distributions of dimension and preserved wet weight from trawl-caught specimens (black) and estimated from photographs (grey) for: (A,F) Daontesia porcupina (diameter); $(\mathrm{B}, \mathrm{G})$ Amphianthus bathybium (diameter); $(\mathrm{C}, \mathrm{H})$ Styracaster spp. (radius); (D,I) Ophiuroidea (radius), and (E,J) Psychropotes longicauda (length)

sonal and inter-annual variations in individual size. However, the trawl-caught specimens did not always include the full range of dimensions determined from the photographs. The size classes of taxa in photographs overlapped those from the trawls, but for some taxa, smaller or larger individuals were measured in the photographs (e.g. Fig. 2E). This comparison pro- vides an indirect validation of the dimensions measured in photographs, as there was no drastic difference in sizes, and indicates the broad equivalency of sizes between trawled and photographed specimens, suggesting that the application of our conversions was appropriate. However, extrapolation of conversions beyond the size ranges of the trawl-caught specimens may not be appropriate.

The use of the oral disk to column diameter conversion in the 4 actiniarian taxa resulted in a substantial improvement in the correspondence of size classes between photographs and trawls. For example, of 86 individuals of Daontesia porcupina (RiemannZürneck 1997a) identified in photographs, 72 were larger than the range of trawled specimens without the conversion; this was reduced to 2 after the conversion was applied. Similarly, of 259 photographed individuals of Amphianthus bathybium (Hertwig \& Herdman 1882), 234 were larger than the trawl-measured size range, reduced to only 8 after conversion. Further improvements to this method for anemones, and other taxa that retract or shrink substantially upon collection, could be made by photographing and collecting specific individuals in situ, given sufficient ROV time.

Published conversions between preserved and fresh wet weights in deep-sea taxa are also scarce. Here we have included conversions for as many taxa as possible (Table 4), even where sample numbers were low. Nevertheless, the goodness of fit was generally high $\left(\mathrm{R}^{2}=0.93-0.998\right)$.

Taxa with substantial proportions of soft tissues, such as some holothurians, tunicates, sipunculids, and cephalopods, appear to lose 35 to $60 \%$ of their fresh wet mass on preservation. This is similar to the loss estimated generally for holothurians $(40 \%)$ by Billett et al. (2001) from data on shallow-water species given by Conand (1989). Taxa with greater proportions of hard/structural tissues, such as asteroids, some arthropods, and gastropods, lose 10 to $20 \%$ of their fresh wet weight on preservation. Our estimates do not consider changes in preserved wet weights with time, which have been studied in shallow-water polychaetes and amphipods (Gaston et al. 1996, Wetzel et al. 2005). For example, Mills et al. (1982) found that wet weight increased immediately after fixation in formalin, followed by a reduction in wet weight over time. As our specimens were preserved for at least 2 months prior to measurement, their wet weights may have largely stabilised, as potentially suggested by the high $\mathrm{R}^{2}$ values (Table 4 ).

The development of wet weight conversions from photographic dimensions for a wide range of taxa will facilitate the improved estimation of deep-sea 
Table 4 . Fresh wet weight to preserved wet weight conversions in the form: preserved wet weight $(\mathrm{g})=J \times$ fresh wet weight (g) (see Eq. 3), where $J$ is a factor determined by linear regression with zero intercept

\begin{tabular}{|c|c|c|c|}
\hline Taxon & $J$ & $\mathrm{R}^{2}$ & $\mathrm{n}$ \\
\hline \multicolumn{4}{|l|}{ ANNELIDA } \\
\hline Polynoidae & 0.812 & 0.995 & 6 \\
\hline \multicolumn{4}{|l|}{ ARTHROPODA } \\
\hline Cirripedia & 0.751 & 0.98 & 11 \\
\hline Pycnogonida & 0.838 & 0.98 & 9 \\
\hline Cerataspis spp. & 0.781 & 0.97 & 4 \\
\hline Stereomastis spp. & 0.822 & 0.99 & 8 \\
\hline Munida spp./Munidopsis spp. & 0.780 & 0.98 & 7 \\
\hline \multicolumn{4}{|l|}{ CNIDARIA } \\
\hline \multicolumn{4}{|l|}{ Actiniaria } \\
\hline Iosactis vagabunda & 0.887 & 0.99 & 13 \\
\hline Parasicyonis biotrans & 0.784 & 0.998 & 7 \\
\hline Daontesia porcupina & 0.818 & 0.99 & 8 \\
\hline Actinauge abyssorum & 0.722 & 0.99 & 13 \\
\hline Amphianthus bathybium & 0.664 & 0.95 & 13 \\
\hline Segonzactis platypus & 0.681 & 0.98 & 9 \\
\hline Sicyopus commensalis & 0.966 & 0.96 & 9 \\
\hline Zoanthidea & 0.755 & 0.99 & 5 \\
\hline Umbellula spp. & 0.656 & 0.98 & 9 \\
\hline \multicolumn{4}{|l|}{ ECHINODERMATA } \\
\hline Asteroidea & & & \\
\hline Pythonaster atlantidis & 0.845 & 0.999 & 3 \\
\hline $\begin{array}{l}\text { Styracaster chunil } \\
\text { Styracaster horridus }\end{array}$ & 0.873 & 0.999 & 10 \\
\hline Dytaster grandis grandis & 0.820 & 0.998 & 11 \\
\hline Hyphalaster inermis & 0.873 & 0.99 & 8 \\
\hline Freyella spp./Freyastera spp. & 0.886 & 0.99 & 12 \\
\hline Pterasteridae & 0.820 & NA & 1 \\
\hline \multicolumn{4}{|l|}{ Holothuroidea } \\
\hline Amperima rosea & 0.627 & 0.995 & 13 \\
\hline Benthodytes spp. & 0.470 & 0.99 & 8 \\
\hline Deima validum validum & 0.648 & 0.98 & 12 \\
\hline Ellipinion spp./Kolga spp. & 0.460 & 0.99 & 10 \\
\hline Zygothuria candelabri & 0.604 & 0.96 & 12 \\
\hline Oneirophanta mutabilis & 0.539 & 0.99 & 6 \\
\hline Paroriza prouhoi & 0.527 & 0.96 & 10 \\
\hline Peniagone spp. & 0.684 & 0.93 & 11 \\
\hline $\begin{array}{l}\text { Pseudostichopus aemulatus/ } \\
\text { Molpadiodemas villosus/ } \\
\text { Pseudostichopus spp. }\end{array}$ & 0.413 & 0.93 & 11 \\
\hline $\begin{array}{l}\text { Psychropotes longicauda/ } \\
\text { Psychropotes semperiana } \\
\text { (Théel 1882) }\end{array}$ & 0.505 & 0.96 & 6 \\
\hline Molpadia spp. & 0.576 & 0.98 & 9 \\
\hline Crinoidea & 0.680 & 0.94 & 8 \\
\hline Echinoidea & 0.570 & NA & 1 \\
\hline Ophiuroidea & 0.835 & 0.996 & 10 \\
\hline ECHIURA & 0.670 & 0.99 & 6 \\
\hline \multicolumn{4}{|l|}{ MOLLUSCA } \\
\hline Cephalopoda & 0.415 & 0.99 & 7 \\
\hline Gastropoda & 0.861 & 0.99 & 13 \\
\hline Bivalvia & 0.715 & 0.97 & 8 \\
\hline TUNICATA & 0.657 & 0.99 & 8 \\
\hline SIPUNCULA & 0.649 & 0.99 & 5 \\
\hline PORIFERA & 0.791 & 0.97 & 8 \\
\hline
\end{tabular}

megafaunal biomass from the large numbers of seabed photographs now being routinely captured in many studies (e.g. Morris et al. 2014, Wynn et al. 2014). The improved quantification of benthic megafaunal biomass using photographs (see e.g. Christiansen \& Thiel 1992, and expanded upon here) can be illustrated with key taxa from the PAP. Holothurians dominate the biomass at the PAP and their temporal variation has long been the focus of research (Billett et al. 2001, 2010), while the dominance of cnidarians has only recently been appreciated (Durden et al. 2015b). Billett et al. (2010) estimated mean holothurian biomass across all trawls over the years 1989-2005 at 1903 (95\% CI = 1693-2138) g wet weight ha ${ }^{-1}$, cnidarian biomass at 44 (38-51) g wet weight $\mathrm{ha}^{-1}$, and that of total invertebrates at 2111 (1888-2359) g wet weight ha ${ }^{-1}$. Durden et al. (2015a) employed a towed camera survey and preliminary conversions to wet weight from photographs, and estimated total invertebrate biomass at the PAP at $24200 \mathrm{~g}$ wet weight ha ${ }^{-1}, 8$ times the highest value reported by Billett et al. (2010). Holothurian and cnidarian biomass were estimated at 18500 and $5400 \mathrm{~g}$ preserved wet weight $\mathrm{ha}^{-1}$, respectively, 10 and 125 times the values reported by Billett et al. (2010). Using the conversions presented here, and the photographic survey reported by Morris et al. (2014) at the PAP site, holothurian biomass was estimated at $36200 \mathrm{~g}$ fresh wet weight ha ${ }^{-1}$, and cnidarian biomass at $9200 \mathrm{~g}$ fresh wet weight ha ${ }^{-1}$. These estimates are each twice those given by Durden et al. (2015a), and 19 and 214 times the estimates by Billett et al. (2010). The sum of holothurian and cnidarian biomass is 20 times the Billett et al. (2010) value for total invertebrate biomass. Given these dramatic uplifts in megabenthic biomass over trawled estimates from the PAP, it is clear that biomass estimation by this method will have a profound effect on studies of standing stocks, community metabolism, and the numerical modelling of carbon flows (e.g. van Oevelen et al. 2012).

Acknowledgements. We thank the captains and crews of research cruises RRS 'Discovery' 222, 226, 229, 231, 237, 266 and 377, and RRS 'Challenger' 135 and 142. This project was dependent upon the long-term curation of ecological specimens by the Discovery Collections, National Oceanography Centre, Southampton, UK. This work was funded by the UK Natural Environment Research Council (NERC), and contributes to the Autonomous Ecological Surveying of the Abyss project (NERC NE/H021787/1), the NERC Marine Environmental Mapping Programme (MAREMAP), and the Porcupine Abyssal Plain-Sustained Observatory (NERC National Capability programme). 


\section{LITERATURE CITED}

Alt CHS, Rogacheva A, Boorman B, Hughes JA, Billett DSM, Gooday AJ, Jones DOB (2013) Trawled megafaunal invertebrate assemblages from bathyal depth of the MidAtlantic Ridge $\left(48^{\circ} \mathrm{W}-54^{\circ} \mathrm{N}\right)$. Deep-Sea Res II 98: 326-340

Bailey TG, Torres JJ, Youngbluth MJ, Owen GP (1994) Effect of decompression on mesopelagic gelatinous zooplankton: a comparison of in situ and shipboard measurements of metabolism. Mar Ecol Prog Ser 113:13-27

Bett BJ (1998) RRS Discovery Cruise 229, 02 Jul-31 Jul 1997. BENGAL: high resolution and spatial study of the benthic biology and geochemistry of a north-eastern Atlantic abyssal locality. Southampton Oceanography Centre Cruise Report 15. Southampton Oceanography Centre, Southampton

Bett BJ (2013) Characteristic benthic size spectra: potential sampling artefacts. Mar Ecol Prog Ser 487:1-6

> Bett BJ, Malzone MG, Narayanaswamy BE, Wigham BD (2001) Temporal variability in phytodetritus and megabenthic activity at the seabed in the deep Northeast Atlantic. Prog Oceanogr 50:349-368

Billett DSM (1998) RRS Challenger Cruise 135, 15 Oct30 Oct 1997. BENGAL: high resolution temporal and spatial study of the benthic biology and geochemistry of a north-eastern Atlantic abyssal locality. Southampton Oceanography Centre Cruise Report 19. Southampton Oceanography Centre, Southampton

Billett DSM (2000) RRS Challenger Cruise 142, 19 Apr19 May 1999. Temporal and spatial variability of benthic communities on the Porcupine Abyssal Plain and in the Porcupine Seabight. Southampton Oceanography Centre Cruise Report 30. Southampton Oceanography Centre, Southampton

Billett DSM, Bett BJ, Rice AL, Thurston $\mathrm{MH}$, Galeron J, Sibuet M, Wolff GA (2001) Long-term change in the megabenthos of the Porcupine Abyssal Plain (NE Atlantic). Prog Oceanogr 50:325-348

Billett DSM, Bett BJ, Reid WDK, Boorman B, Priede IG (2010) Long-term change in the abyssal NE Atlantic: the 'Amperima Event' revisited. Deep-Sea Res II 57: 1406-1417

Carlgren O (1934) Ceriantharia, Zoantharia and Actiniaria. Report of Scientific Results 'Michael Sars' North Atlantic Deep-sea Expedition 1910 V:1-52

Christiansen B, Thiel H (1992) Deep-sea epibenthic megafauna of the Northeast Atlantic-abundance and biomass at 3 midoceanic locations estimated from photographic transects. NATO Adv Sci I C-Mat 360:125-138

Clark AH (1948) Some interesting starfishes and brittlestars dredged by the 'Atlantis' in the mid-Atlantic. J Wash Acad Sci 38:75-78

Conand C (1989) Les holothuries aspidochirotes du Lagon de Nouvelle-Calédonie. Biologie, écologie et exploitation. Institut Français de recherche Scientifique pour le développement en coopération, Paris

Durden JM, Bett BJ, Jones DOB, Huvenne VAI, Ruhl HA (2015a) Abyssal hills - hidden source of increased habitat heterogeneity, benthic megafaunal biomass and diversity in the deep sea. Prog Oceanogr 137(Part A): 209-218

Durden JM, Bett BJ, Ruhl HA (2015b) The hemisessile lifestyle and feeding strategies of Iosactis vagabunda (Actiniaria, Iosactiidae), a dominant megafaunal species of the Porcupine Abyssal Plain. Deep-Sea Res I 102: $72-77$

Gage JD, Bett BJ (2005) Deep-sea benthic sampling. In: Eleftheriou A, McIntyre A (eds) Methods for the study of marine benthos. Blackwell Science, Oxford, p 273-325

Gage JD, Tyler PA (1991) Deep-sea biology: a natural history of organisms at the deep-sea floor. Cambridge University Press, Cambridge

Gaston GR, Bartlett JHW, McAllister AP, Heard RW (1996) Biomass variations of estuarine macrobenthos preserved in ethanol and formalin. Estuaries 19:674-679

> Gravier C (1918) Note préliminaire sur les Hexactiniaires recueillis au cours des croisières de la Princesse-Alice et de l'Hirondelle de 1888 à 1913 inclusivement. Bull Inst Océanogr Monaco 346:1-24

- Hartman SE, Lampitt RS, Larkin KE, Pagnani M and others (2012) The Porcupine Abyssal Plain fixed-point sustained observatory (PAP-SO): variations and trends from the Northeast Atlantic fixed-point time-series. ICES J Mar Sci 69:776-783

Hérouard E (1902) Holothuries provenant des campagnes de la Princesse-Alice: 1892-1897. Imprimerie de Monaco

Hérouard E (1923) Holothuries provenant des campagnes des yachts Princesse-Alice et Hirondelle II: 1898-1915. Imprimerie de Monaco

Hertwig R (1882) Report on the Actiniaria dredged by H.M.S. Challenger during the years 1873-1876. Reports of Science Research Voyage of HMS Challenger. Zoology $6: 1-136$

Jamieson A, Boorman B, Jones DOB (2013) Deep-sea benthic sampling. In: Eleftheriou A (ed) Methods for the study of marine benthos. John Wiley \& Sons, Chichester, p 285-348

Jones DOB, Bett BJ, Wynn RB, Masson DG (2009) The use of towed camera platforms in deep-water science. Int J Soc Underwater Technol 28:41-50

Kelly-Gerreyn BA, Martin AP, Bett BJ, Anderson TR and others (2014) Benthic biomass size spectra in shelf and deep-sea sediments. Biogeosciences 11:6401-6416

Ludwig H (1907) Diagnosen neuer Tiefsee Seesterne aus der Familie der Porcellanasteriden. Zool Anz 31:312-319

Mills EL, Pittman K, Munroe B (1982) Effect of preservation on the weight of marine benthic invertebrates. Can J Fish Aquat Sci 39:221-224

Morris KJ, Bett BJ, Durden JM, Huvenne VAI and others (2014) A new method for ecological surveying of the abyss using autonomous underwater vehicle photography. Limnol Oceanogr Methods 12:795-809

Owen DM, Sanders HL, Hessler RR (1967) Bottom photography as a tool for estimating benthic populations. In: Hersey JB (ed) Deep-sea photography, Book No. 3. The Johns Hopkins Press, Baltimore, MD, p 29-234

Perrier E (1886) Les explorations sous marines. Hachette

R Core Team (2015) R: a language and environment for statistical computing. R Foundation for Statistical Computing, Vienna. www.r-project.org

Rex MA, Etter RJ, Morris JS, Crouse J and others (2006) Global bathymetric patterns of standing stock and body size in the deep-sea benthos. Mar Ecol Prog Ser 317:1-8

Rice AL (1996) RRS Discovery Cruise 222, Leg 2, 29 Aug24 Sep 1996. BENGAL: high resolution temporal and spatial study of the benthic biology and geochemistry of a north-eastern Atlantic abyssal locality. Southampton Oceanography Centre Cruise Report 4. Southampton Oceanography Centre, Southampton 
Rice AL (1997) RRS Discovery Cruise 226, 12 Mar-10 Apr 1997. BENGAL: high resolution temporal and spatial study of the benthic biology and geochemistry of a northeastern Atlantic abyssal locality. Southampton Oceanography Centre Cruise Report 13. Southampton Oceanography Centre, Southampton

Rice AL (1998) RRS Discovery Cruise 231, 28 Feb-30 Mar 1998. BENGAL: high resolution temporal and spatial study of the benthic biology and geochemistry of a northeastern Atlantic abyssal locality. Southampton Oceanography Centre Cruise Report 18. Southampton Oceanography Centre, Southampton

Rice AL, Aldred RG, Billett D, Thurston MH (1979) The combined use of an epibenthic sledge and a deep-sea camera to give quantitative relevance to macro-benthos samples. Ambio Spec Rep 6:59-72

Riemann-Zürneck K (1979) Two disc-shaped deep sea Anthozoa from the Gulf of Biscay, with a survey of adaptation types in the Actiniaria. Zoomorphologie 93: $227-243$

Riemann-Zürneck K (1991) A new species of Sicyonis (Actinaria: Actinostolidae) from the abyssal NE Atlantic. Mitt Hambg Zool Mus Inst 88:7-15

Riemann-Zürneck K (1997a) The deep-sea anemones Bathyphellia margaritacea and Daontesia porcupina sp. nov. with comments on the family Bathyphelliidae. J Mar Biol Assoc UK 77:361-374

Riemann-Zürneck K (1997b) A hemisessile sea anemone from the Porcupine Abyssal Plain, North Atlantic Ocean: Iosactis vagabunda gen. nov., sp. nov. J Mar Biol Assoc UK 77:1011-1025

Ruhl H (2013) RRS Discovery Cruise 377 \& 378, 05-27 July 2012. Autonomous ecological surveying of the abyss: understanding mesoscale spatial heterogeneity at the Porcupine Abyssal Plain. Southampton Oceanography Cruise Report 23 National Oceanography Centre, Southampton, Southampton

Ruhl HA, Bett BJ, Hughes SJM, Alt CHS and others (2014) Links between deep-sea respiration and community dynamics. Ecology 95:1651-1662

Sheldon RW, Prakash A, Sutcliffe WH (1972) The size distribution of particles in the ocean. Limnol Oceanogr 17 : $327-340$

Sibuet M (1999) RRS Discovery Cruise 237, 25 Sep-08 Oct 1998. BENGAL: high resolution temporal and spatial study of the benthic biology and geochemistry of a northeastern Atlantic abyssal locality. Southampton Oceanography Centre Cruise Report 23. Southampton Oceanography Centre, Southampton

Simmons JE (2014) Fluid preservation: a comprehensive reference. Rowman \& Littlefield, Plymouth

Sladen WP (1883) The Asteroidea of H.M.S. Challenger Expedition. (Preliminary notices). 2. Astropectinidae. J Linnean Soc Lond Zool 17:214-269

Editorial responsibility: Romuald Lipcius, Gloucester Point, Virginia, USA
Smith CR, Hamilton SC (1983) Epibenthic megafauna of a bathyal basin off southern California: patterns of abundance, biomass, and dispersion. Deep-Sea Res 30: 907-928

Smith CJ, Rumohr H (2013) Imaging techniques. In: Eleftheriou A (ed) Methods for the study of marine benthos. John Wiley \& Sons, Chichester, p 97-124

Solis-Marin FA, Billett DSM, Preston J, Rogers AD (2004) Mitochondrial DNA sequence evidence supporting the recognition of a new North Atlantic Pseudostichopus species (Echinodermata: Holothuroidea). J Mar Biol Assoc UK 84:1077-1084

Théel H (1879) Preliminary report on the Holothuridae of the exploring voyage of H.M.S. 'Challenger' under Professor Sir C. Wyville Thomson F.R.S. Part 1. Communicated to the Royal Swedish Academy of Sciences June 11. Bihang till $\mathrm{K}$ Svenska Vetensk Akad Handlingar 5(19):1-20

Théel H (1882) Report on the Holothuroidea dredged by H.M.S. 'Challenger' during the years 1873-1876. Part i. Report on the Scientific Results of the Voyage of HMS 'Challenger'. Zoology 4(13):1-176

Théel H (1886a) Report on Holothurioidea of the Blake expeditions 1877-1880. Bull Mus Comparative Zool Harvard College 13:1-21

Théel H (1886b) Report on the Holothurioidea dredged by the HMS Challenger during the years 1873-1876. Part II. Report on the Scientific Results of the Voyage of HMS Challenger 1873-1876. Zoology 14:1-290

Thresher RE, Adkins J, Fallon SJ, Gowlett-Holmes K, Althaus F, Williams A (2011) Extraordinarily high biomass benthic community on Southern Ocean seamounts. Sci Rep 1:119

van Oevelen D, Soetaert K, Heip C (2012) Carbon flows in the benthic food web of the Porcupine Abyssal Plain: the (un)importance of labile detritus in supporting microbial and faunal carbon demands. Limnol Oceanogr 57: 645-664

Verrill AE (1884) Notice of the remarkable marine fauna occupying the outer banks off the southern coast of New England; No. 9, Brief contributions to zoology from the Museum of Yale College; No. LV. Am J Sci 28:213-220

> Wei CL, Rowe GT, Escobar-Briones E, Boetius A and others (2010) Global patterns and predictions of seafloor biomass using random forests. PLoS ONE 5:e15323

> Wetzel M, Leuchs H, Koop JE (2005) Preservation effects on wet weight, dry weight, and ash-free dry weight biomass estimates of four common estuarine macro-invertebrates: no difference between ethanol and formalin. Helgol Mar Res 59:206-213

- Wynn RB, Huvenne VA, Le Bas TP, Murton BJ and others (2014) Autonomous underwater vehicles (AUVs): their past, present and future contributions to the advancement of marine geoscience. Mar Geol 352:451-468

Submitted: January 21, 2016; Accepted: May 10, 2016 Proofs received from author(s): June 13, 2016 